\title{
The effect of the service quality on passengers' satisfaction
}

\author{
Sakkarin Nonthapot ${ }^{\mathrm{a}}$ and Angwara Nasoontorn ${ }^{\mathrm{a}^{*}}$
}

\begin{tabular}{|c|c|}
\hline CHRON I C L E & A B S T RA C T \\
\hline $\begin{array}{l}\text { Article history: } \\
\text { Received: March 18, } 2020 \\
\text { Received in revised format: } \\
\text { May } 302020 \\
\text { Accepted: June 17, } 2020 \\
\text { Available online: } \\
\text { June 17, 2020 } \\
\text { Keywords: } \\
\text { Service quality } \\
\text { SERVQUAL } \\
\text { Ferry } \\
\text { Thailand }\end{array}$ & $\begin{array}{l}\text { The objective of this research was to investigate the impacts of the perceived service quality on } \\
\text { passengers' satisfaction towards the service quality of the Nakhon Phanom Municipality, Thailand } \\
\text { - Thakhek, Lao People's Democratic Republic ferry. The sample group comprised Thai and Lao } \\
\text { passengers who used the ferry's service. A questionnaire was used to collect data from } 505 \text { samples } \\
\text { who were selected using the simple random sampling method. The collected data was analyzed } \\
\text { using the confirmatory factor analysis (CFA), structural equation modelling (SEM), and partial } \\
\text { least squares (PLS) regression with the ADANCO } 2.1 .1 \text { software. The results showed that the per- } \\
\text { ceived service quality consisted of tangible, reliability, responsiveness, assurance, and empathy, } \\
\text { which had the same impact with the passengers' satisfaction towards the service quality. The most } \\
\text { influential factors were the tangible and responsiveness. Therefore, entrepreneurs should prioritize } \\
\text { the improvement and development of the ferry's tangible. Furthermore, the government sector or } \\
\text { relevant agencies should promote the implementation of technology into the development in order } \\
\text { to fulfill the passengers' demand and create an impression that would lead to satisfaction and re- } \\
\text { purchasing. }\end{array}$ \\
\hline
\end{tabular}

\section{Introduction}

Land, water and air transport have been very crucial for traffic, trade, as well as human, animals and cargo transportation for a long time. Transport is also an activity that has been related to humans who have always travelled for different purposes. For this reason, transport is very significant for a country's development because efficient transport generates economic activities that can lead to rapid urbanization and international relations. Moreover, the cargo transportation system has an effect on tourism that encourages more domestic and international travel. Nakhon Phanom is a province in Northeastern Thailand that is located on the west bank of the Maekong River. The eastern part is adjacent to Khammouane Province, Lao People's Democratic Republic (Lao PDR). Furthermore, Nakhon Phanom Province and Thakhek District in Khammouane Province, Lao PDR have some related historical tourist sites and unique cultures, as well as the Third Thai-Lao Friendship Bridge and a ferry port. This is also a permanent checkpoint for transportation and products exchange that is very beneficial for both countries in terms of their economy and trade (Fig. 1 and Fig. 2). The arrival and departure statistics from Nakhon Phanom to Thakhek from 2013 to 2018, the number of passengers who travelled through the Third Thai-Lao Friendship Bridge Checkpoint differed to those who used the ferry through the permanent checkpoint at the Tourism Port, Nakhon Phanom Immigration. Moreover, from the statistics of the aforementioned period, the number of passengers at both checkpoints had reduced; the reduction at the Tourism Port permanent checkpoint was more obvious than that at the Third Thai-Lao Friendship Bridge Checkpoint (Nakhon Phanom Immigration Office, 2020). This reflected that there were problems with the quality of the ferry service, which might transform the travel behavior of international passengers to use more land transport via the Third ThaiLao Friendship Bridge (Table 1).

* Corresponding author.

E-mail address: aungna@kku.ac.th (A. Nasoontorn) 


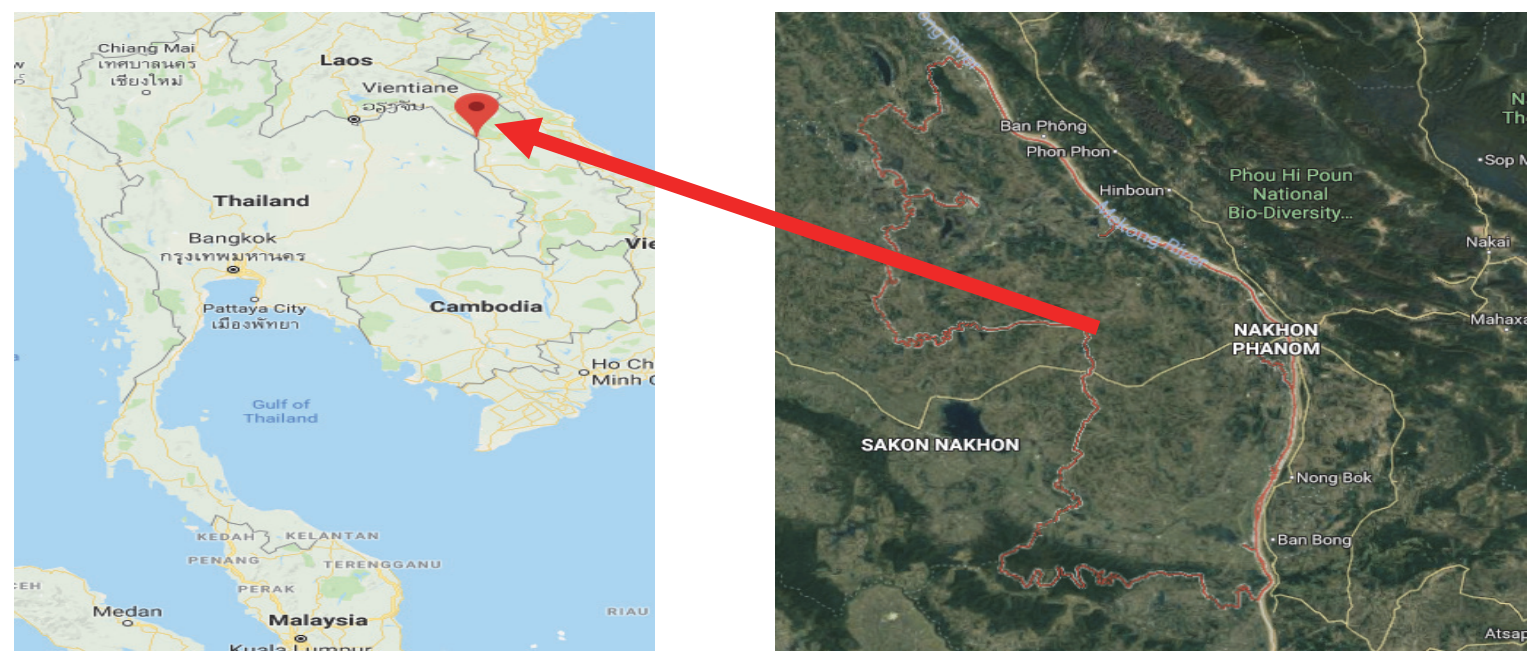

Fig. 1. Location of Nakhon Phanom Province

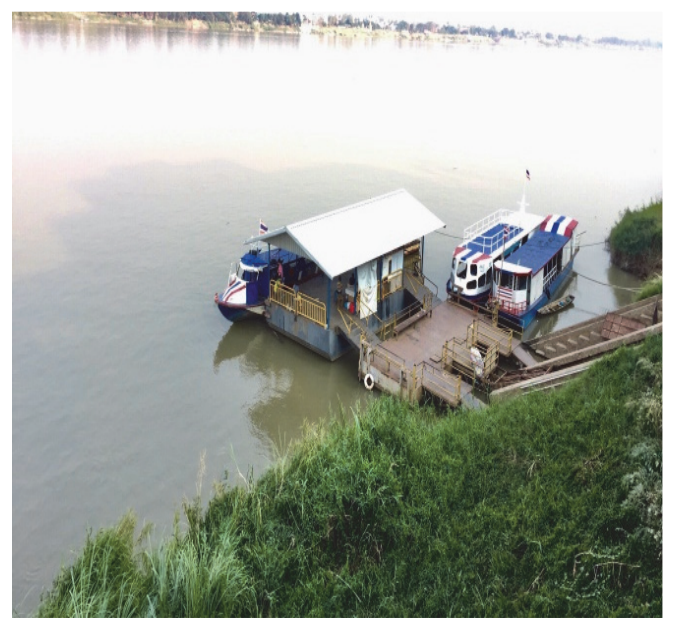

(a)

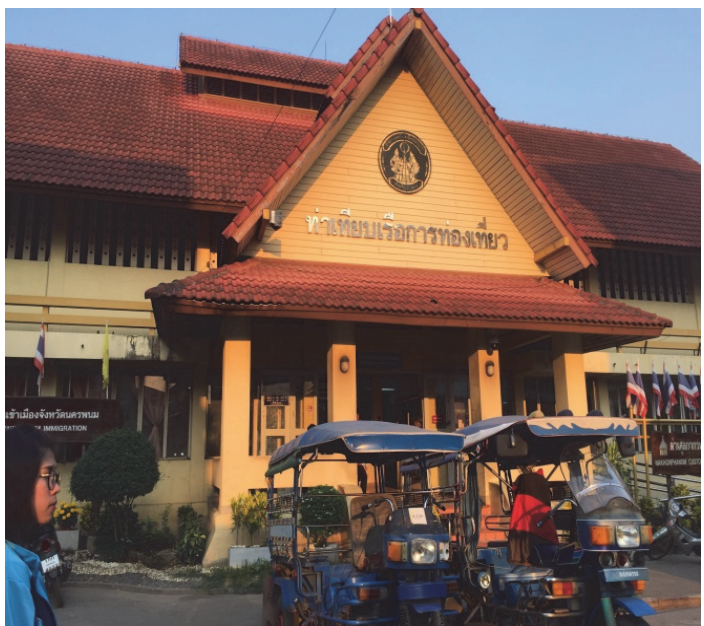

(b)

Fig. 2. (a) Nakhon Phanom Municipality Pier; (b) Tourism Port, Nakhon Phanom Immigration.

Table 1

Statistics of the arrivals and departures between Nakhon Phanom-Thakhek.

\begin{tabular}{|c|c|c|c|c|}
\hline \multirow[t]{2}{*}{ Fiscal year } & \multicolumn{2}{|c|}{$\begin{array}{c}\text { Number of People at the Third Thai-Lao Friendship } \\
\text { Bridge Checkpoint (prs.) }\end{array}$} & \multicolumn{2}{|c|}{$\begin{array}{l}\text { Number of People at the Tourism Port Checkpoint } \\
\text { (prs.) }\end{array}$} \\
\hline & Arrivals & Departures & Arrivals & Departures \\
\hline 2013 & 178,390 & 165,769 & 124,877 & 122,225 \\
\hline 2014 & 186,110 & 185,245 & 125,312 & 122,567 \\
\hline 2015 & 161,157 & 158,227 & 77,407 & 73,060 \\
\hline 2016 & 158,224 & 151,167 & 54,830 & 50,112 \\
\hline 2017 & 135,485 & 137882 & 53,336 & 41,007 \\
\hline 2018 & 134,791 & 135,842 & 42,983 & 33,037 \\
\hline
\end{tabular}

Source: Modified from the Nakhon Phanom Immigration Office (2020).

A ferry is a service that is an intangible activity where one party offers a sale to another party who has no right to substantially possess such service. The service process might also be concurrent with the distribution of intangible products (Nonthapot \& Thomya, 2020). Thus, the service is related to a sale, operation or any action offered to another party who has no right to possess such service like other products (Srisawat, 2003: P.15-20; Behera, 2020). Moreover, service quality is a component that should be retained and performed with zero errors in order to understand and fulfil the service users' demand. Furthermore, service quality should be taken into consideration since it is very important to a business's success. Simultaneously, the area in Nakhon Phanom is very popular for the local people and tourists, so service quality, which is obtained from the actual perception minus the expectation of the service, should be analyzed to understand its importance. If the perceived service is lower than the expectation, this would represent a low service quality or poor service to the service user. On the other hand, if it is higher than the expectation, this would be considered as a good quality service (Schmenner, 1995 cited in Srisawat, 
2003: P.11; Rahahleh et al., 2020). For this reason, the study on the impact of the perceived quality service on passengers' satisfaction towards the service quality of the Nakhon Phanom Municipality-Thakhek ferry should be examined by analyzing the passengers' behavior, so that entrepreneurs could respond to the demand and fulfill the users highest satisfaction. The study results could be applied to the business improvement and development plan, as well as to be used as a reference for the development of the transportation system.

\section{Literature Review}

SERVQUAL is generally used as a tool to measure the quality of service that consists of five dimensions: 1) tangible, 2) reliability, 3) responsiveness, 4) assurance, and 5) empathy. Mahatma et al. (2015) developed a model for measuring the logistics service quality of public land transport, which was called P-TRANSQUAL that comprises four quality indicators involving 1) comfort representing the convenience and safety for the passenger, 2) tangible demonstrating the efficiency of the public transport system performance in terms of sensible and tangible physical comfort, 3) personnel signifying the efficiency of the public transport system's performance that would be related to the service provider, as well as the manner, willingness and understanding in the passengers' demand, and 4) reliability representing a method to construct passengers' trust in the public transport system (Santiphap \& Sangasaphaviriya, 2015). When considering shipping, its features and service are consistent with the SERQUAL concept. Thus, the five-dimensional quality assessment would be more inclusive than PTRANSQUAL, so it should be implemented into service businesses, as this would provide significance to the service users' expectations in order to respond to their demand and fulfil their satisfaction. SERQUAL involves a multidimensional quality indicator, so the service provider would recognize the weakness of the service and the service users' demand, which would be useful for the development of service quality and the fulfilment of satisfaction. In order to assess service quality, the service user should mainly focus on consumer satisfaction, which represents the consumer's feeling towards something. Kotler (1997) stated that the level of customer satisfaction was the result of the comparison of the benefits of products or the product itself and the customer's expectation. With regard to service quality assessment in Thailand, Jangvechchai (2016, P.45-48) investigated service quality affecting passengers' satisfaction towards the Bangkok Mass Transit System (BTS) Skytrain in Bangkok and discovered that reliability, assurance and understanding affected the satisfaction of the passengers. This finding conformed with the study of Ngamsom \& Saensook (2017) that tangible, reliability, responsiveness, and understanding had an impact on the users' satisfaction. Additionally, Lue-rit (2017); Arayarungsee (2013, P.50-52) found that the qualities of an electronic service in terms of reliability, responsiveness, system preparedness, safety and security, association, intelligibility, sufficiency, and service attentiveness were related to the users' satisfaction. Therefore, the above literature review reflected that the perceived service quality had an impact on satisfaction that eventually led to the research framework. Thus, the factors of service quality, which consisted of tangible, reliability, responsiveness, assurance, and empathy, affected the passengers' satisfaction towards the service quality of the Nakhon Phanom Municipality, Thailand-Thakhek, Lao PDR ferry (Figure 3).

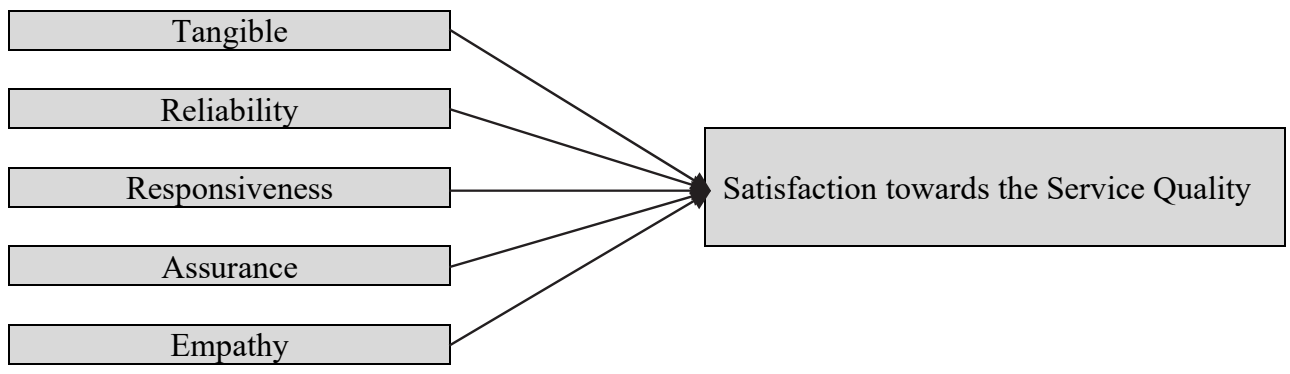

\section{Research Methodology}

Fig. 3. Research framework

\subsection{Population and Sample Group}

The population group consisted of Thai and Lao passengers who travelled through the Tourism Port, Nakhon Phanom Immigration. However, the exact number of the population was unidentified. The sample group was the people who arrived and departed from the aforementioned checkpoint, and the reliability level was 95 percent. The W.G. Cochran method was used to calculate the size of the sample group (Cochran, 1997 cited in Nonthapot, 2019), and 384.16 samples were obtained. This research utilized confirmatory factor analysis (CFA) in order to have the robustness and appropriate size of the sample group for the data analysis. The suitable sample size was up to 500 samples (Thaireuakham, 2009, P.20-24) though the number of samples of this research was finally 505 samples. A questionnaire was used to collect the data from the sample group, who was selected by a convenient sampling method consisting of Thai and Lao passengers, which were counted as 90 percent of all passengers.

\subsection{Research Tools}

A questionnaire, which the index of item-objective congruence (IOC) was $\geq 0.6$ (Nonthapot, 2019) was used to collect the data from the passengers who used the service of the Nakhon Phanom Municipality-Thakhek (Lao PDR) ferry. From the pretest with 30 samples, the reliability of the questionnaire was 0.92 . 
Descriptive statistics to analyze the general information of the respondents and the behavior of the ferry users included frequency and percentage. A structural equation model (SEM) was utilized to analyze the impact of the perceived service quality on the passengers' satisfaction towards the service quality of the Nakhon Phanom Municipality-Thakhek (Lao PDR) ferry. Partial least square (PLS) regression and CFA were applied to examine the construct validation of the latent variables. Moreover, ADANCO 2.1.1 was used to analyze the consistency of the model's relationship. A goodness of fit model was considered from Bartlett's Test of Sphericity, which should contain a high value and be different from a zero value with a statistical significance, and a Chi-square $\left(\chi^{2}\right)$ that should have a significance of $0.05(\mathrm{P}>0.05)$. The value of the Chi-square $\left(\chi^{2}\right)$ divided with the degrees of freedom should be lower than 2 (Tabachnick \& Fidell, 2007: P.45-58; Thi et al., 202) while the root mean square error of approximation (RMSEA) should be lower than 0.07(Steiger, 2007). Furthermore, the standardized root mean squared residual (standardized SRMR) should be lower than 0.08 (Hu \& Bentler, 1999) while the comparative fit index (CFI) and Tucker-Lewis index (TLI) should be higher than 0.95 .

\section{Results}

\subsection{General Information of the Sample}

The reliability of the questionnaire was tested by using Cronbach's Alpha, which the value was 0.95 showing that it was reliable. The general information of the 505 samples showed that most passengers were married females (53.5\%) aged between 31-40 years. Most had graduated with a bachelor's degree and worked at a company. Their average income was 25,00135,000 Thai Baht. The majority (31.5\%) travelled for tourism purposes, and they travelled by ferry one-two times per month $(78.2 \%)$ and mostly on the weekend (98.6\%).

\subsection{The Perceived Service Quality of the Passengers' Satisfaction towards the Service Quality of the Ferry}

The analysis using the SEM was divided into the three following steps.

\subsubsection{Model quality analysis}

The results show that the overall quality of the model, which was taken from the consideration of the evaluation of the model and the measuring of three statistics values: SRMR, dG and dULS, was lower than $95 \%$ of its own bootstrap quantile. This reflected that the quality of the model was appropriate and efficient to use for explaining the data (Table 2).

Table 2

Quality of the model

\begin{tabular}{lcccccc}
\hline \multirow{2}{*}{ Statistics } & \multicolumn{3}{c}{$\begin{array}{c}\text { Goodness of Fit Model } \\
\text { (Saturated Model) }\end{array}$} & & \multicolumn{3}{c}{$\begin{array}{c}\text { Goodness of Fit Model } \\
\text { (Estimated Model) }\end{array}$} \\
\cline { 2 - 7 } & Value & HI95 & HI99 & Value & HI95 & HI99 \\
\hline SRMR & 0.0878 & 0.0337 & 0.0356 & 0.0878 & 0.0337 & 0.0356 \\
$\mathrm{~d}_{\mathrm{ULS}}$ & 3.5834 & 0.5285 & 0.5906 & 3.5834 & 0.5285 & 0.5906 \\
$\mathrm{~d}_{\mathrm{G}}$ & 2.0458 & 0.3699 & 0.4045 & 2.0485 & 0.3698 & 0.4043 \\
\hline Souryyyyyyyyyyyy
\end{tabular}

Source: From the calculation.

\subsubsection{Analysis of measuring the model or outer model}

The estimation was the reflective model with the loading showing the validity and reliability. The reliability was measured with Cronbach's alpha $(\alpha)$ and Dijkstra-Henseler's rho $\left(\rho_{\mathrm{A}}\right)$. The value of the Cronbach's alpha $(\alpha)$ was $0.8237-0.9266$ while the value of Dijkstra-Henseler's rho $\left(\rho_{\mathrm{A}}\right)$ was $0.8255-0.9286$. Thus, the measurement was reliable.

\subsubsection{Analysis of the structural model or inner model}

The structural model was estimated from the loading or path coefficient and $\mathrm{R}^{2}$, which both statistics values were at a high level with positive statistical significance. Hair et al. (2010: P.100-156) studied the $\mathrm{R}^{2}$ of the variables of satisfaction towards the service quality and found that the value was 0.910 , which was substantial. The opinions about the perceived service quality on the passengers' satisfaction towards the service quality of the Nakhon Phanom Municipality-Thakhek (Lao PDR) ferry indicated five effects, which all of them had a direct impact on the satisfaction. It was found that tangible to satisfaction had the highest effect $(0.2732)$, followed by responsiveness to satisfaction $(0.2611)$, assurance to satisfaction $(0.2369)$, empathy to satisfaction (0.1986), and reliability to satisfaction (0.1969) (Table 3$)$. Furthermore, when considering Cohen's $\mathrm{f}^{2}$, it showed that tangible, responsiveness, and assurance had a moderate impact on the satisfaction towards the service quality whereas reliability and empathy had a low impact. The results are shown in Fig. 4. 
Table 3

Effects of the variables of the opinions about the perceived service quality of the passengers' satisfaction towards the ferry service quality

\begin{tabular}{|c|c|c|c|c|}
\hline Effect & $\begin{array}{c}\text { Beta } \\
\text { (Direct Effects) }\end{array}$ & $\begin{array}{l}\text { Indirect } \\
\text { Effects }\end{array}$ & Total Effect & $\begin{array}{c}\text { Cohen's } \\
\mathrm{f}^{2}\end{array}$ \\
\hline Tangible $\rightarrow$ Satisfaction & $0.2732 * * *$ & - & 0.2732 & 0.4416 \\
\hline Reliability $\rightarrow$ Satisfaction & $0.1969 * * *$ & - & 0.1969 & 0.1587 \\
\hline Responsiveness $\rightarrow$ Satisfaction & $0.2611 * * *$ & - & 0.2611 & 0.3059 \\
\hline Assurance $\rightarrow$ Satisfaction & $0.2369 * * *$ & - & 0.2369 & 0.2349 \\
\hline Empathy $\rightarrow$ Satisfaction & $0.1986 * * *$ & - & 0.1986 & 0.1900 \\
\hline
\end{tabular}

Note: $* * *$ Acceptable at a reliability of $99 \%$.

Source: From the calculation.

\section{Graphical representation of the model}

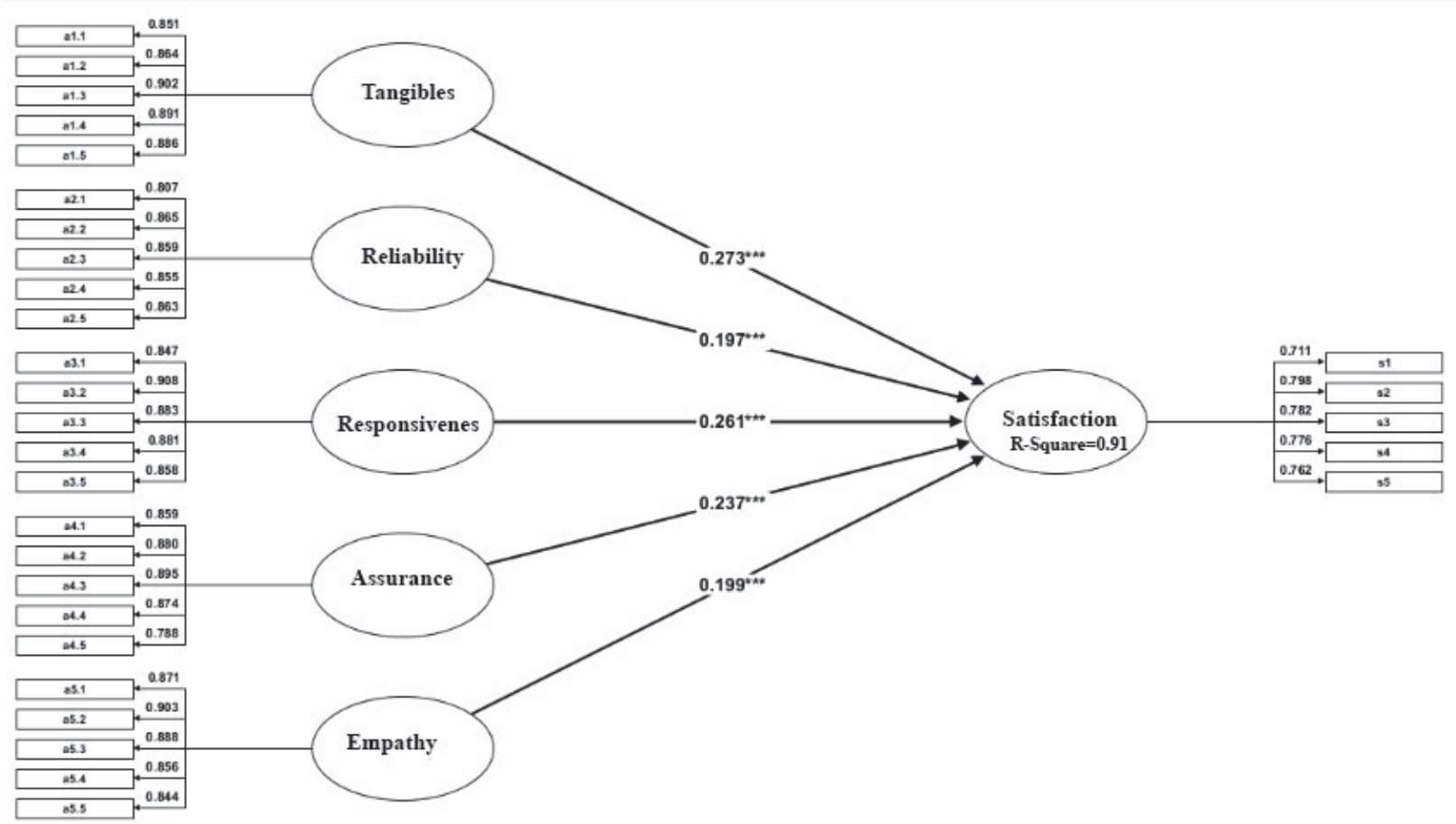

\section{Conclusion}

Fig. 4. Result of the consistency of the model's relationship.

The factors of service quality comprised tangible, reliability, responsiveness, assurance, and empathy that led to the passengers' satisfaction towards the service quality of the Nakhon Phanom Municipality-Thakhek (Lao PDR) ferry. The results from the SEM estimation showed that the R-Square value was 0.91, where all Cronbach Alpha values were higher than 0.80 . Consequently, this demonstrated that the results could predict the internal value (Chin, 1998). Therefore, the explanation of the results obtained from the PLS-SEM was reliable. The analysis of the results was summarized as follows:

Tangible had a huge impact on the satisfaction towards the service quality, which included the appropriate attire of the employees, simple accessibility; such as, ticket sales, high-tech security equipment, sufficient seating capacity, especially the cleanliness, which the service users put as a top priority. Thus, the service provider should pay attention to these aspects and continue improving and developing them. When considering the responsiveness, it also affected the satisfaction towards the service quality, which included the preparedness of the service, staff's enthusiastic service mind, noticing any problems, timeliness, as well as passenger assistance and support that would maximize the satisfaction of the service user, as they were concerned with the safety and security of the passenger in any case of emergency. For this reason, the service provider should provide prompt support and aid to passengers in order to minimize any damage and show responsibility. The government and other relevant agencies should also promote the implementation of technology into the development to fulfil the passengers' demand. Reliability, assurance, and empathy had a positive relationship to satisfaction; the average impact was up to 20 percent. This represented that all three factors reflected the quality of the ferry service. Thus, the important details of the reliability of the service included creating a positive impression to the passengers while travelling, good manners and constant polite service, timeliness, and zero errors of the operation; such as, giving clear instructions on the ticket sales because international transport would be more complex than general transport. Nevertheless, in terms of assurance, the capability to perform the assigned tasks should be prioritized; such as, an experienced navigator, standardized service safety and reliability, 
and polite service should be performed constantly to satisfy the passengers. Additionally, sincere care for the passengers should emphasize equality without prejudice, a friendly and enthusiastic service, approachable interaction, and direct and clear suggestions and advice on the service to respond to each passenger in order to impress them, which would finally result in satisfaction and repurchase. Hence, entrepreneurs should priorities the improvement and development of the ferry's tangible. The government sector or relevant agencies should promote the implementation of technology into the development in order to fulfill the passengers' demand and create an impression that would lead to satisfaction and repurchasing.

\section{References}

Arayarungsee, S. (2013). Effect of service quality on customers' satisfaction of the financial services on the Bangkok bank's Internet system in Nakhon Ratchasima Province. Rajamangala University of Technology Isan Nakhon Ratchasima, Master of Business Administration thesis.

Behera, A. (2020). Quality of Indian service industries with different ANN models. International Journal of Data and Network Science, 4(1), 15-26.

Chin, W.W. (1998). The partial least squares approach to structural equation modeling. In G. A. Marcoulides (Ed.), Modern methods for business research (295-336). Mahwah, New Jersey: Lawrence Erlbaum Associates.

Cochran, W. G. (1977). Sampling Techniques. 3rd edition. New York: John Wiley \& Sons.

Hair, J. F., Black, B., Babin, B., Anderson, R. E. \& Tatham, R. L. (2010). Multivariate Data analysis: a global perspective. New Jersey: Pearson Education.

Hu, L. T., \& Bentler, P. M. (1999). Cutoff criteria for fit indexes in covariance structure analysis: Conventional criteria versus new alternatives. Structural Equation Modeling, 6, 1-55.

Jangvechchai, B. (2016). Service Quality Affecting to Passenger's Satisfaction BTS Skytrain in Bangkok. Bangkok University, Master of Business Administration Independent Study.

Nakhon Phanom Immigration Office (2020). International Statistic Report. Retrieved from

http://www.nakhonphanom-imm.com/. Accessed [20 Jan 2020].

Kotler, P. (1997). Marketing Management: Analysis Planning Implementing and Control. $9^{\text {th }}$ ed., USA: Prentice Hall.

Lue-rit, P. (2017). Quality of Electronic Service for the Users' Satisfaction: A Case Study of the Mobile Wallet Application. 2017. Thammasat University, Master of Science Thesis.

Mahatma, I. G., Bakti, Y. \& Sumaedi, S. (2015). PTRANSQUAL a service quality model of public land transport services. International Journal of Quality \& Reliability Management, 32(6). 534-558.

Ngamsom, S., \& Saensook, J. (2017). Healthcare service quality perceptions and insured patient's satisfaction of hospital service systems in Phra Nakhon Sri Ayutthaya Province. Humanities, Social Science, and Arts, 10(3), 1392-1408. [In Thai].

Nonthapot, S. (2019). Thai Tourists Choice of Accommodation based on Marketing Behaviors in Vang Vieng Town, Lao People's Democratic Republic. Journal of Environmental Management and Tourism, 10(4). 725-734.

Nonthapot, S. \& Thomya, W. (2020). The effect of the marketing mix on the demand of Thai and foreign tourists. Management Science Letters. 10(11). 2437-2446.

Rahahleh, A., Al-Nsour, S., Moflih, M., Alabaddi, Z., Al-nassar, B., \& Al-Nsour, N. (2020). The influence of electronic service quality on relationship quality: Evidence from tourism industry. Management Science Letters, 10(12), $2759-2768$.

Santiphap, Eakasit, \& Sangasaphaviriya, Jongkolbodin (2015). Logistics service quality of public land transport service by PTransqual Model: Thailand - Luang Prabang Case Study. RMUTL Journal, 3(2), 72-83.

Schmenner, R. W. (1988). Escaping the black holes of cost accounting. Business Horizons, 31(1), 66-72.

Srisawat, N. (2003). Expectation and Perceived Service Quality of Khlong Saen Saep Ferry. Srinakharinwirot University, Master of Business Administration Independent Study.

Steiger, J. H. (2007). Understanding the limitation of global fit assessment in structural equation modeling. Personality and Individual Differences, 42, 893-898.

Tabachnick, B.G., \& Fidell, L.S. (2007). Using Multivariate Statistics, (5 $5^{\text {th }}$ eds). Boston: Pearson Education, Inc.

Thaireuakham, S. (2009). Advance Statistics for Educational Research. Kalasin, Thailand: Prasan Printing.

Thi, K., Huy, T., Van, C., \& Tuan, P. (2020). The effects of service quality on international tourist satisfaction and loyalty: Insight from Vietnam. International Journal of Data and Network Science, 4(2), 179-186.

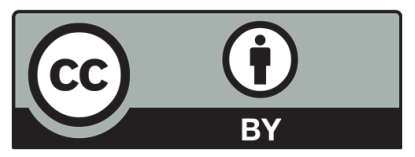

(C) 2020 by the authors; licensee Growing Science, Canada. This is an open access article distributed under the terms and conditions of the Creative Commons Attribution (CC-BY) license (http://creativecommons.org/licenses/by/4.0/). 